\title{
O USO DA MEDIDA PROVISÓRIA ANTES DA EMENDA CONSTITUCIONAL 32/2001 E O PRINCÍPIO DEMOCRÁTICO
}

\author{
WILSON STEINMETZ*
}

1. A medida provisória na Constituição Federal antes da EC 32/200I - 2. O princípio democrático na Constituição Federal de 1988; 2.1 Fundamentos constitucionais; 2.2 Conteúdo normativo; 2.2.1 Dimensões do princípio democrático; 2.2.2 Elementos constitutivos do princípio democrático; 2.3 Princípio democrático e inovação normativa da ordem jurídica - 3. O uso da medida provisória antes da EC 32/2001 e o princípio democrático; 3.1 Compatibilidade no plano da normatividade constitucional abstrata; 3.2 Os Poderes Públicos, o uso da medida provisória antes da EC 32/2001 e o princípio democrático; 3.2.1 Poder Executivo; 3.2.2 Poder Legislativo (Congresso Nacional); 3.2.3 Supremo Tribunal Federal; Referências bibliográficas

\begin{abstract}
RESUMO: Analisa-se o uso da medida provisória antes da Emenda Constitucional 32/2001 à luz do princípio democrático. Argumenta-se que em tese (in abstracto) não há incompatibilidade entre o instrumento legislativo medida provisória e o princípio democrático. Contudo, in concreto, o excesso de medidas provisórias editadas e reeditadas pelo Poder Executivo, bem como a omissão do Congresso Nacional e a interpretação política do caput e do parágrafo único do art. 62 (na redação anterior à EC 32/2001) não estavam em conformidade com o princípio democrático.
\end{abstract}

Neste texto, analisa-se o uso do instrumento legislativo medida provisória no regime anterior à Emenda Constitucional 32/2001 à luz do princípio democrático. Inicialmente, descreve-se a conformação constitucional da medida provisória antes da EC 32/2001; depois se propõe uma interpretação dos fundamentos e do conteúdo

* Doutor em Direito (UFPR). Professor do Mestrado em Direito da Universidade Luterana do Brasil (RS) e do Mestrado em Direito da Universidade de Caxias do Sul (RS).

R. Dir. Adm.,

Rio de Janeiro, 237: 143-164,

Jul./Set. 2004 
constitucionais do princípio democrático; e, por fim, analisam-se, à luz do princípio democrático, o uso que fez o Poder Executivo da medida provisória antes da EC 32/2001 e a posição do Poder Legislativo (Congresso Nacional) e do Supremo Tribunal Federal ante esse uso do Poder Executivo.

A análise sobre o uso da medida provisória após a EC 32/2001 aqui não é objeto. Se, de um lado, constata-se que o Poder Executivo continua fazendo uso excessivo da medida provisória, de outro lado, ainda não estão claramente definidas as posições do Poder Legislativo (Congresso Nacional) e do Supremo Tribunal Federal ante esse uso excessivo, já que alguns problemas relativos ao uso da medida provisória (e.g., reedição e matérias) foram atenuados com a regulamentação mais específica da EC $32 / 2001$ e a mudança de governo é recente.

De um modo geral, na literatura especializada, analisou-se e criticou-se o uso abusivo da medida provisória na perspectiva do princípio da separação de poderes, ficando em segundo plano, quando não esquecido, o princípio democrático. Essa é, por si só, uma razão suficiente para justificar a análise aqui desenvolvida.

\section{A medida provisória na Constituição Federal antes da EC 32/2001}

$\mathrm{O}$ caput do art. 62 da Constituição Federal $(\mathrm{CF})$ - na redação anterior à EC 32/2001 - enunciava que, "em caso de relevância e urgência, o Presidente da República poderá adotar medidas provisórias, com força de lei, devendo submetê-las de imediato ao Congresso Nacional, que, estando em recesso, será convocado extraordinariamente para se reunir no prazo de cinco dias". O parágrafo único do mesmo artigo prescrevia que "as medidas provisórias perderão eficácia, desde a edição, se não forem convertidas em lei no prazo de trinta dias, a partir de sua publicação". A medida provisória, como instrumento de introdução de enunciados normativos na ordem jurídica, era, e ainda é, uma das espécies do processo legislativo ( $\mathrm{CF}$, art. 59, V). A competência para edição, no âmbito federal, é privativa do Presidente da República (CF, art. 84, XXVI).

$\mathrm{O}$ instrumento medida provisória era, e continua sendo após a EC 32/2001, providência legislativa excepcional e de caráter emergencial, como claramente indicam os pressupostos materiais para sua edição - relevância e urgência. A nãoconfiguração conjunta da relevância e da urgência proíbe o chefe do Poder Executivo Federal de editá-la, porque já fora de sua competência legislativa. Trata-se de competência constitucional excepcional de edição, de uma competência juridicamente delimitada. ${ }^{~}$ É ainda providência legislativa de caráter provisório, como indica o próprio nome, que não dispensa a participação do Congresso Nacional (controle parlamentar), a quem compete a conversão da medida provisória em lei. Por isso, dizia-se que a edição de medida provisória estava sujeita a uma condição resolutiva: a continuidade da vigência e da eficácia de normas veiculadas por medida provisória

1 A expressão é de Humberto Bergmann Ávila (Medida provisória na Constituição de 1988. Porto Alegre: S. A. Fabris, 1997, p. 24). 
dependia de aprovação do Congresso Nacional, que tinha poderes para rejeitá-la, expressa ou tacitamente.

$\mathrm{Na}$ história constitucional brasileira, o antecedente imediato à medida provisória foi o decreto-lei, previsto pela Emenda Constitucional $n^{\circ} 1$ de $1969 .{ }^{2} \mathrm{Na}$ literatura constitucional após-88, esse dado histórico é sempre relembrado quando da análise jurídica da medida provisória. A comparação entre medida provisória e decreto-lei torna mais evidentes o sentido e a finalidade constitucionais daquela. Na comparação, dava-se (e ainda se dá) ênfase às diferenças para demonstrar que a medida provisória é inequivocamente instrumento excepcional de veiculação de normas com força de lei. Ademais, a origem da medida provisória situou-se em contexto constitucional diferenciado: enquanto a Emenda Constitucional $n^{\circ} I$ (1969), que previa o decreto-lei, foi produto de um regime de força, com opção por um Estado autoritário, a CF de 1988; introdutora da medida provisória, é produto de uma assembléia constituinte democrática, com expressa opção pelo Estado Democrático de Direito.

Para os fins deste artigo, é dispensável retomar reconstrutivamente toda a análise comparativa, desenvolvida na literatura constitucional especializada, entre a medida provisória - tal como era disciplinada antes da EC 32/2001 - e o decreto-lei. ${ }^{3}$ Contudo, para rememorar, é oportuno apresentar uma síntese das diferenças entre os dois instrumentos legislativos. Clève, com clareza e concisão - o que justifica uma citação textual mais longa - enumera as diferenças pontuadas na literatura especializada:

“(...) há importantes diferenças entre a medida provisória e o antigo decreto-lei. Deveras, (i) os pressupostos autorizadores não são exatamente os mesmos. A medida provisória pode ser adotada em caso de relevância e

2 “Art. 55. O Presidente da República, em casos de urgência ou de interesse público relevante, e desde que não haja aumento de despesa, poderá expedir decretos-leis sobre as seguintes matérias:

1 - segurança nacional;

II - finanças públicas, inclusive normas tributárias; e

III - criação de cargos públicos e fixação de vencimentos.

$\S 1^{\circ}$ - Publicado o texto, que terá vigência imediata, o decreto-lei será submetido pelo Presidente da República ao Congresso Nacional, que o aprovará ou rejeitará. dentro de sessenta dias a contar do seu recebimento, não podendo emendá-lo; se, nesse prazo, não houver deliberação, aplicar-se-á o disposto no $\S 3^{\circ}$ do art. 51 .

$\S 2^{\circ}$ - A rejeição do decreto-lei não implicará a nulidade dos atos praticados durante a sua vigência."

"Art. 51, $\S 3^{\circ}-\mathrm{Na}$ falta de deliberação dentro dos prazos estipulados neste artigo e parágrafos anteriores, considerar-se-ão aprovados os projetos."

A Emenda Constitucional $n^{\circ} 22$, de 1982 , deu nova redação ao $\S 3^{\circ}$, do art. 51 : "Na falta de deliberação dentro dos prazos estabelecidos neste artigo e no parágrafo anterior, cada projeto será incluído automaticamente na ordem do dia, em regime de urgência, nas dez sessões subsequentes em dias sucessivos; se, ao final dessas, não for apreciado, considerar-se-à definitivamente aprovado".

3 Análise pormenorizada encontra-se em Humberto Ávila, Medida provisória na Constituiçāo de 1988 , p. $27-42$ 
urgência (os dois pressupostos reclamam realização simultânea); já o decreto-lei tinha como supostos habilitantes a urgência ou o interesse público relevante; (ii) o Executivo não estava, por intermédio de decreto-lei, autorizado a aumentar as despesas públicas, sendo certo que esta restrição não ocorre em relação às medidas provisórias; (iii) a eficácia temporal da medida provisória corresponde a trinta dias, enquanto a do decreto-lei era de sessenta dias; (iv) a Constituição de 1988 não definiu, expressamente, as matérias suscetíveis de tratamento pela medida provisória; já a Constituição revogada autorizava a adoção de decretos-leis, apenas, nos casos de a) segurança nacional, $b$ ) finanças públicas, inclusive normas tributárias e $c$ ) criação de cargos públicos e fixação de vencimentos; (v) se não convertidas em lei no prazo constitucionalmente definido, as medidas provisórias perdem eficácia desde a sua edição (ex tunc); já os decretos-leis, ultrapassado o prazo de sessenta dias, observado o disposto no art. $51, \S 3^{\circ}$ da Constituição revogada, com a redação oferecida pela Emenda Constitucional 22/82, sem manifestação do Congresso Nacional, eram tidos por aprovados; (vi) conquanto não haja disposição expressa a respeito, tem-se que, no processo de conversão da medida provisória em lei formal, pode o Legislativo valer-se do poder de emenda; ao contrário, o texto constitucional anterior vedava expressamente a possibilidade de qualquer tipo de emendas ao decreto-lei; (vii) a rejeição da medida provisória ou a sua não conversão em lei no prazo de trinta dias implica a nulidade dos atos praticados sob a sua égide; o que inocorria na hipótese de rejeição do decreto-lei; (viii) em relação às medidas provisórias há dispositivo conferindo ao Congresso Nacional o dever de regular as relações jurídicas decorrentes em caso de não conversão em lei no prazo previsto; idêntica previsão não teria sentido em relação aos decretos-leis que, caso rejeitados, não implicavam a perda de eficácia ex tunc". ${ }^{4}$

Esse quadro comparativo mostra a conformação jurídico-constitucional distinta de ambos os instrumentos. Na perspectiva do princípio democrático, são de especial relevância a inversão dos efeitos na hipótese de decurso de prazo (não-apreciação do Congresso Nacional) e a possibilidade de emenda no caso da medida provisória.

A medida provisória confirma uma tendência iniciada no século XX: atribuir competência legislativa excepcional ao Poder Executivo. Para justificar os poderes legislativos do Poder Executivo, são apresentados argumentos político-empíricos. O argumento mais frequiente é o de que é necessário dotar o Poder Executivo de poderes legislativos excepcionais e emergenciais, dada a complexidade das sociedades contemporâneas e a ampliação significativa da intervenção estatal nos domínios econômico e social. A complexidade social e a crescente intervenção do Estado exigem um Poder Executivo ágil, eficaz e suficientemente instrumentalizado para dar conta dos inúmeros problemas concretos e imediatos; problemas cuja solução nem sempre

4 CLĖVE, Clèmerson Merlin. Medidas provisórias. 2. ed. rev. ampl. São Paulo: Max Limonad, 1999 , p. 39-40. 
pode aguardar providências normativas do Poder Legislativo, por natureza um poder de Estado mais lento, porque suas decisões dependem de ampla discussão e metódica deliberação. Um Poder Executivo sem instrumentos legislativos excepcionais e emergenciais tende, em certos casos, para a paralisia administrativa e até mesmo para o estado de ingovernabilidade.

Esse argumento, de caráter político-empírico, com pretensões de validade geral no âmbito de sociedades complexas, teve peso destacado nos debates da Assembléia Constituinte brasileira (1987-1988). De um modo geral, ressaltava-se a necessidade de o Poder Legislativo recuperar as prerrogativas específicas perdidas durante o regime militar, contudo reconhecia-se também a necessidade de dotar o Poder Executivo de instrumentos que impedissem a paralisia, dada a complexidade dos problemas de governo e o natural alongamento temporal do processo legislativo decisório. ${ }^{5}$

Ainda no plano da justificação político-empírica, há também um argumento específico para o caso brasileiro. Diz-se que o Poder Executivo precisa ter competência legislativa excepcional por força do elevado número de partidos políticos com representação no Congresso Nacional e pela falta de unidade e disciplina partidárias. A pulverização e fragmentação partidárias tornam a negociação entre o Poder Executivo e o Poder Legislativo mais complexa e lenta. Sem instrumentos de inovação normativa do sistema jurídico, em situação de relevância e urgência, o Poder Executivo poderia ficar refém do Congresso Nacional. Ademais, ante problemas cujas soluções são impopulares há uma tendência à passividade do Parlamento, arcando o Poder Executivo com o maior desgaste junto à opinião pública.

Ambos os argumentos têm origem na Ciência Política. Poderia argumentar-se que juridicamente não são relevantes, porque argumentos estritamente empíricos não referidos ao sistema constitucional positivo. Contudo, uma análise menos restrita mostra que esses argumentos não são excludentes do enfoque dogmático-constitucional. Se não, veja-se. O primeiro argumento diz que as competências legislativas do Poder Executivo decorrem da complexidade da sociedade e da ampliação da intervenção estatal. Ora, uma análise relativamente simples da ordem econômica e financeira (Título VII, arts. 170-192) e de ordem social (Título VIII, arts. 193-232) da CF já é suficiente para mostrar não só a complexidade da sociedade brasileira até porque, em tese, uma Constituição deve apresentar pautas normativas para o enquadramento das grandes questões de um país -, mas também o conjunto de tarefas a serem cumpridas pelo Estado brasileiro, sobretudo, pela função executiva do Estado. $\mathrm{O}$ segundo argumento diz respeito às relações entre Poder Legislativo $\mathrm{e}$ Poder Executivo mediada pelos partidos políticos com representação no Congresso Nacional. Aqui também uma análise simples das disposições normativas referentes aos partidos políticos revela que a CF não põe obstáculos à pulverização (e.g., não

5 Acerca dos debates na Assembléia Constituinte sobre a medida provisória, ver: FIGUEIREDO, Argelina Cheibub; LIMONGI, Fernando. Executivo e Legislativo na nova ordem constitucional. São Paulo: Ed. FGV, Fapesp, 1999, p. 125-156. 
há cláusula de barreira) e à fragmentação partidárias (a fidelidade partidária está à livre disposição dos partidos políticos - CF, art. $\left.17, \S 1^{\circ}\right)^{6}$

\section{O princípio democrático na Constituição Federal de 1988}

\subsection{Fundamentos constitucionais}

Os fundamentos constitucionais do princípio democrático podem ser divididos em imediatos e mediatos. São fundamentos imediatos o Estado Democrático de Direito (art. $\mathrm{l}^{\circ}$, caput, da $\mathrm{CF}$ ), a soberania popular (art. $1^{\circ}$, parágrafo único, e art. 14, caput, da CF) e o pluralismo político (art. $1^{\circ}, \mathrm{V}$, da CF). ${ }^{7}$ São fundamentos

6 A justificativa político-empírica é também invocada na jurisprudência do Supremo Tribunal Federal. Tome-se como exemplo a manifestação do Ministro Carlos Velloso em voto proferido na ADInMC n 1.516-RO (Rel. Min. Sydney Sanches): "Sr. Presidente, a delegação legislativa é a tônica do Direito Constitucional contemporâneo. Técnicas de delegação legislativa são imaginadas pelos constitucionalistas e pelos cientistas políticos, em obséquio mesmo ao Estado de Direito, no qual a Administração Pública age sempre dando execução à lei e, em última análise, em que nada se faz senão com base na lei. Se é assim, se, nesta quadra de século, o intervencionismo estatal. que é opção dos povos, acumulou um mundo de competências para o Estado e, de regra, ao Executivo, que age dando execução, de ofício, à lei, seria mesmo necessário que se imaginassem técnicas de delegação para que, executando o Poder Executivo esse mundo de competências que o intervencionismo estatal destinou ao Estado, pudesse efetivar essas competências. Então, tem-se, Sr. Presidente. a técnica de se conferir ao Executivo a iniciativa legislativa, a técnica do decreto-lei e dos regulamentos autônomos, a técnica da lei delega [sic], da loi cadre dos franceses.

A Constituição brasileira, engajada no constitucionalismo contemporâneo, adota técnicas de delegação legislativa; a Constituição anterior tinha o decreto-lei e a lei delegada; a Constituição atual, a medida provisória e também a lei delegada" (Revista Trimestral de Jurisprudência 170: 832, doravante $R T J)$.

7 Constata-se a preferência pela soberania popular como o principal fundamento constitucional da democracia. Ilustrativamente, na literatura brasileira, citem-se: Humberto Ávila, Medida provisória na Constituição de 1988, p. 51; SILVA, José Afonso da. Curso de Direito Constitucional Positivo. 9. ed. rev. [4 ${ }^{a}$ tiragem] São Paulo: Malheiros, 1994, p. 119. Na literatura comparada, citem-se: BÖCKENFÖRDE, Ernst Wolfgang. "La democracia como princípio constitucional". In: BÖCKENFÖRDE, Emst Wolfgang. Estudios sobre el Estado de Derecho y la democracia. Madri: Trotta, 2000. p. 47 et seq.; PÉREZ LUÑO, Antônio Henrique. Derechos humanos, Estado de Derecho y Constitución. 6. ed. Madri: Tecnos, 1999, p. 187-211; ASENSISABATER, José. La época constitucional. Valência: Tirant lo Blanch, 1998, p. 134-139. Essa preferência tem uma certa razão de ser, porque afinal desde a antigüidade até os dias de hoje, a despeito das diferentes teorias descritivas e normativas da democracia, o fato é que com democracia quer se designar a forma de governo na qual o poder tem origem no povo e por ele é exercido. Essa noção é invariável ao longo da história ocidental, dos gregos aos contemporâneos. Nesse sentido, ver: BOBBIO, Norberto. Estado, governo, sociedade: para uma teoria geral da política. Trad. de Marco Aurélio Nogueira. 6. ed. Rio de Janeiro: Paz e Terra, 1997, p. 135 et seq. Todavia, por razões óbvias, os princípios do Estado Democrático de Direito e do pluralismo político também constituem fundamento do princípio democrático. Com o princípio do Estado Democrático de Direito determina-se que o Estado que o Poder Constituinte institui é constitutivamente democrático e subordinado ao império 
mediatos, entre outros, o direito fundamental à liberdade (art. $5^{\circ}$, caput), o direito fundamental à livre manifestação do pensamento (art. $5^{\circ}$, IV), o direito fundamental à não-privação de direitos por motivo de convicção política (art. $5^{\circ}$, VIII), a liberdade de associação (art. $\left.5^{\circ}, \mathrm{XVII}\right)$ e a liberdade partidária (art. 17, caput e $\S 1^{\circ}$ ). Esses são fundamentos mediatos nos seguintes sentidos: (i) porque deles se deduz interpretativamente o princípio democrático; (ii) porque a realização desses direitos pressupõe uma ordem democrática; e (iii) porque tais direitos são concretizações do princípio democrático. Assim, mesmo que na CF não houvesse referência à soberania popular, ao Estado Democrático de Direito e ao pluralismo político, a referência às liberdades supramencionadas já seria suficiente para a fundamentação constitucional do princípio democrático.

\subsection{Conteúdo normativo}

O conteúdo normativo do princípio democrático pode ser aferido identificando-se as dimensões que possui e os elementos que o constituem ou o concretizam.

\subsubsection{Dimensões do princípio democrático}

$\mathrm{Na} \mathrm{CF}$, o princípio democrático possui uma dupla dimensão: dimensão normativo-substancial e dimensão normativo-procedimental. ${ }^{8}$ Esse dado constitucional positivo resolve, ao menos no plano normativo, a velha dicotomia "democracia formal versus democracia substancial", que tantas discussões gerou no âmbito da teoria política normativa e da filosofia política normativa.

\subsubsection{Dimensão normativo-procedimental}

A CF opta pela democracia como princípio de organização da titularidade e do exercício do poder político-estatal, como método de os representados-governados (titulares do poder) escolherem seus representantes-governantes. A democracia, nessa dimensão, manifesta-se sob a forma de princípios, regras e procedimentos para o exercício do poder que emana do povo. ${ }^{9} \mathrm{~A}$ CF estabelece e assegura "as regras do

da lei e do Direito. Também existe uma imbricação evidente entre democracia e pluralismo político; aquela não existe sem este. Democracia sem pluralismo político é simulacro, é farsa.

8 Essa distinção é feita por Canotilho (Direito Constitucional e Teoria da Constituição, p. 277-278) ao descrever a democracia como princípio normativo da Constituição da República Portuguesa (1976). Essa distinção também se ajusta à descrição da democracia na $C F$.

9 Do ponto de vista analítico-conceitual, a dimensão procedimental é útil para uma definição mínima de democracia. Cite-se Bobbio: "afirmo preliminarmente que o único modo de se chegar a um acordo quando se fala de democracia, entendida como contraposta a todas as formas de governo autocrático, é o de considerá-la caracterizada por um conjunto de regras (primárias ou fundamentais) que estabelecem quem está autorizado a tomar as decisões coletivas e com quais procedimentos" (BOBBIO, Norberto. O futuro da democracia: uma defesa das regras do jogo. Trad. de Marco Aurélio Nogueira. 5. ed. Rio de Janeiro: Paz e Terra, 1992, p. 18). 
jogo": eleições periódicas e livres, pelo sufrágio universal e pelo voto direto e secreto, com valor igual para todos (CF, art. 14, caput). Institui ainda como forma de exercício da soberania popular o plebiscito, o referendo e a iniciativa popular (CF, art. 14,1, II e III).

\subsubsection{Dimensão normativo-substancial}

A democracia na CF não se restringe aos aspectos formais e procedimentais; não é apenas um princípio organizador, um método ou técnica de exercício do poder. Nitidamente, possui uma dimensão substantiva, porque se apresenta como um valor fundamental constitucionalizado e como condição para a realização de outros valores e objetivos havidos como fundamentais pelo Poder Constituinte. Enfatize-se que já no preâmbulo declara-se que o Estado Democrático de Direito que a CF institui destina-se " $[\ldots]$ a assegurar o exercício dos direitos sociais e individuais, a liberdade, a segurança, o bem-estar, o desenvolvimento, a igualdade e a justiça como valores supremos de uma sociedade fraterna, pluralista e sem preconceitos [...]". Essa enunciação preambular e os objetivos fundamentais da República Federativa do Brasil enumerados no art. $3^{\circ} \mathrm{e}$ incisos revelam a dimensão substantiva (normativoaxiológica) do princípio democrático. O Poder Constituinte optou pelo regime democrático como um regime de valor (bom e desejável) e como condição para a realização de determinados valores ("valores supremos") e objetivos fundamentais.

Ademais, é evidente, na CF, a vinculação da democracia política à democracia sócio-econômica. Inúmeras são as referências constitucionais reconduzíveis à democracia sócio-econômica: bem-estar, desenvolvimento, igualdade e justiça (preâmbulo); erradicação da pobreza e da marginalidade e redução das desigualdades sociais e regionais (art. $3^{\circ}$, III, e art. 170, VII); direitos fundamentais sociais (Título II, Capítulo II); justiça social (art. 170, caput, e art. 193) e busca do pleno emprego (art. 170, VIII).

Essa conformação normativa da democracia implica que a legitimidade do exercício do domínio político (do poder) depende não só de aspectos formais e procedimentais, mas também de ações praticadas em conformidade com os valores e objetivos para os quais o regime democrático foi instituído. Em outras palavras, a CF exige a observância da democracia e dos valores e objetivos a serem realizados mediante o exercício democrático do poder político. Conseqüência relevante disso é que os poderes públicos (Poder Legislativo, Poder Executivo e Poder Judiciário) deverão atentar para a legitimação continuada do (exercício do) poder político. Dizendo de outro modo, o problema da legitimação/legitimidade do (exercício do) poder político não se esgota no procedimento ou na forma (e.g., no processo eleitoral periódico, com universalidade do sufrágio, voto direto e secreto, e igualdade de voto - CF, art. 14, caput); requer também a vinculação permanente aos valores (supremos, segundo o preâmbulo da $\mathrm{CF}$ ) e objetivos fundamentais especificados pelo texto constitucional. O princípio democrático, a legitimidade do exercício do poder político e os valores (supremos) e objetivos fundamentais da República Federativa do Brasil mantêm entre si um nexo material, funcional e finalístico. 


\subsubsection{Elementos constitutivos do princípio democrático}

São identificáveis no mínimo quatro elementos ou subprincípios constitutivos do princípio democrático: (i) soberania popular; (ii) representação popular ou representação democrática/ (iii) democracia participativa ou democracia semidireta; e (iv) pluralismo político. Esses elementos constitutivos podem ser denominados de elementos concretizantes do princípio democrático.

(i) Soberania popular. A soberania popular confunde-se com o princípio democrático. A CF estabelece que "todo o poder emana do povo [...]" (art. $1^{\circ}$, parágrafo único). O povo é a fonte (origem) e o titular do poder político. Segundo a clássica fórmula de Abraham Lincoln, "governo do povo, pelo povo e para o povo". Böckenförde descreve com precisão o conteúdo do princípio da soberania popular:

“(...) o princípio da soberania do povo se apóia em duas idéias: a de que o poder que exerce o domínio político - o domínio de homens sobre homens - não é algo que esteja simplesmente dado ou que tenha de supor-se, senão que é algo que necessita ser deduzido mediante uma justificação (legitimação), e a [idéia] de que essa legitimação somente pode partir do povo mesmo e não de qualquer instância alheia a ele. A ordenação da vida em comum de um povo tem que poder retrotrair-se ao reconhecimento daqueles que vivem sob ela, tem que ser expressão da liberdade e da autodeterminação do povo." 10

(ii) Representação popular ou representação democrática. "Todo o poder emana do povo, que o exerce por meio de representantes [...]" [sem grifo no original] $\left(\mathrm{CF}\right.$, art. $1^{\circ}$, parágrafo único). O poder emana do povo, contudo o exercício se dá por meio de representação. Trata-se de delegação do (e não de renúncia ao) exercício do poder. Nas palavras de Canotilho, "a representação democrática significa, em primeiro lugar, a autorização dada pelo povo a um órgão soberano, institucionalmente legitimado pela Constituição (criado pelo poder constituinte e inscrito na lei fundamental), para agir autonomamente em nome do povo e para o povo". " A representação divide-se em democrática formal e democrática material. A representação democrática formal é a "autorização e legitimação jurídico-formal concedida a um órgão 'governante' (delegação da vontade) para exercer o poder político [...]". ${ }^{12}$ Contudo, a representação democrática não se reduz à "delegação da vontade do povo"; ela possui também uma dimensão substantiva. Trata-se destas idéias: (a) representação não apenas no lugar do (em substituição ao) povo, mas no interesse do povo; (b) "representação como

10 Ernst Wolfgang Böckenförde, "La democracia como principio constitucional", p. 48.

11 J. J. Gomes Canotilho, Direito Constitucional e Teoria da Constituição, p. 282.

12 Id., ibid., p. 283. 
disposição para responder (responsiveness, na terminologia norte-americana), ou seja, sensibilização e capacidade de percepção dos representantes para decidir em congruência com os desejos e necessidades dos representados, afectados e vinculados pelos actos dos representantes"; e (c) "representação como processo dialéctico entre representantes e representados no sentido de uma realização actualizante dos momentos ou interesses universalizáveis do povo e existentes no povo (não em puras ideias de dever ser ou em valores apriorísticos)" ${ }^{13}$

(iii) Democracia participativa ou democracia semidireta. "Todo o poder emana do povo, que o exerce por meio de representantes ou diretamente[...]" ${ }^{14}$ único, pode induzir à conclusão de que com o termo diretamente institui-se também a democ [sem grifo no original] ( $\mathrm{CF}$, art. $1^{\circ}$, parágrafo único). A democracia participativa ou semidireta se operacionaliza mediante o plebiscito, o referendo e a iniciativa popular (CF, art. 14, I, II e III).

(iv) Pluralismo político $\left(\mathrm{CF}\right.$, art. $\left.1^{\circ}, \mathrm{V}\right)$. Ao prescrever o pluralismo político como um dos fundamentos da República Federativa do Brasil, a CF, em primeiro lugar, reconhece a multiplicidade de interesses, pretensões, projetos e modos de vida existentes na sociedade brasileira - a CF pretende ser uma estrutura normativa básica (fundamental) para uma sociedade pluralista - e, em segundo lugar, ordena que as tensões, os dissensos, os conflitos, os antagonismos micro e macropolíticos sejam explicitados e resolvidos mediante um processo democrático. Ao adotar o pluralismo político, a CF abdica de impor um específico modelo de sociedade, monolítico e fechado. Nesse sentido, a CF não é uma camisa-de-força político-normativa. Corretamente, ela qualifica de modo genérico a sociedade que deve ser construída: uma sociedade fraterna, pluralista, sem preconceitos, livre, justa e solidária (preâmbulo e art. $\left.3^{\circ}, \mathrm{I}\right) .^{15}$

13 ld., ibid., p.283.

14 Uma interpretação apressada e isolada do art. $1^{\circ}$, parágrafo ibilidade na CF: "a Lei Fundamental não normaliza 'democracia' no sentido de um modelo completo e perfeito, senão somente em certos traços fundamentais, ao ela criar as regras indispensáveis para a função da ordem democrática e ao ela procurar assegurar constitucionalmente bases e estruturas fundamentais dessa ordem. Dentro desse quadro, ela deixa a questão sobre o conteúdo da democracia a cargo da discussão política livre; há, portanto, espaço para a realização de idéias diferentes" (HESSE, Konrad. Elementos de Direito Constitucional da República Federal da Alemanha. Trad. de Luís Afonso Heck. Porto Alegre: S. A. Fabris, 1998, p. 117, número de margem 129).

15 É oportuno citar o que escreveu Hesse sobre a democracia na Lei Fundamental alemã (1949), porque encontra referibilidade na CF: “a Lei Fundamental não normaliza 'democracia' no sentido de um modelo completo e perfeito, senão somente em certos traços fundamentais, ao ela criar as regras indispensáveis para a função da ordem democrática e ao ela procurar assegurar constitucionalmente bases e estruturas fundamentais dessa ordem. Dentro desse quadro, ela deixa a questão sobre o conteúdo da democracia a cargo da discussão política livre; há, portanto, espaço para a realização de idéias diferentes" (HESSE, Konrad. Elementos de Direito Constitucional da República Federal da Alemanha. Trad. de Luís Afonso Heck. Porto Alegre: S. A. Fabris, 1998, p. 117 , número de margem 129 ). 


\subsection{Princípio democrático e inovação normativa da ordem jurídica}

No âmbito da produção normativa, tem especial incidência o princípio democrático. Esse dado constitucional positivo é de alta relevância para a análise aqui desenvolvida. ${ }^{16}$

Em um Estado constitucional - no caso brasileiro denominado Estado Democrático de Direito - “[...] a lei parlamentar é, ainda, a expressão privilegiada do princípio democrático (daí a sua supremacia) e o instrumento mais apropriado e seguro para definir os regimes de certas matérias, sobretudo dos direitos fundamentais e da vertebração democrática do Estado (daí a reserva de lei)" ${ }^{17}$ Dizendo de outro modo, trata-se da posição preferente da lei parlamentar como veículo para a inovação da ordem jurídica.

A afirmação de que a lei é uma via privilegiada de concretização do princípio democrático encontra fundamentos explícitos na CF. Ao optar pela representação democrática como forma de exercício da soberania popular (art. $1^{\circ}$, parágrafo único), ao definir o pluralismo político como fundamento da República Federativa do Brasil (art. $1^{\circ}, \mathrm{V}$ ) e ao estabelecer um procedimento legislativo aberto à pluralidade de interesses e pretensões do povo e a possibilidade de uma formação livre da decisão final (a lei votada), a CF reforça a lei como manifestação por excelência do princípio democrático no plano da produção normativa. Ademais, o Congresso Nacional " [...] é o centro qualitativo da produção legislativa (arts. 48 e 49), justamente porque incorpora o princípio democrático antes da produção de efeitos do ato normativo". ${ }^{18}$ Dizendo de outro modo, a participação democrática e pluralista é elemento essencial da formação da lei. Nesse sentido, é correto dizer que a lei parlamentar tem maior valor democrático agregado do que, por exemplo, a medida provisória. Adotada a definição de Alexy, segundo a qual "os princípios são normas que ordenam que algo seja realizado na maior medida possível, dentro das possibilidades jurídicas e reais existentes", ${ }^{19}$ é correio afirmar que a lei traduz uma otimização maior do princípio democrático do que a medida provisória. Contudo, como se argumenta a seguir, isso não significa que a medida provisória, ao menos como disciplinada na CF (mesmo antes da EC 32/2001), é incompatível com o conteúdo e a função do princípio democrático na ordem político-constitucional.

\section{O uso da medida provisória antes da EC 32/2001 e o princípio democrático}

Até agora foram descritos, resumidamente, a conformação constitucional da medida provisória antes da EC 32/2001 e o conteúdo do princípio democrático na

16 Sobre a relevância da incidência do princípio democrático na produção normativav, ver Humberto Ávila. Medida Provisória na Constituição de 1988, p. 51-53.

17 J. J. Gomes Canotilho, Direito Constitucional e Teoria da Constituição, p. 249. No mesmo sentido, ver José Afonso da Silva, Curso de Direito Constitucional Positivo, p. 110.

18 Humberto Ávila, Medida Provisória na Constituição de 1988, p. 52.

19 ALEXY, Robert. Teoria de los derechos fundamentales. $1^{\text {a }}$ reimpressão. Madri: Centro de Estúdios Constitucionales, 1997, p. 86. 
CF. Feito isso, passa-se à relação entre medida provisória e princípio democrático. Em primeiro lugar, desenvolve-se uma breve análise in abstracto (plano da normatividade constitucional abstrata) da relação entre medida provisória e princípio democrático: em segundo lugar, uma análise in concreto (plano da normatividade constitucional concreta ou concretizada), isto é, uma análise do uso efetivo da medida provisória antes da EC 32/2001 pelo Poder Executivo ante o princípio democrático e a posição do Poder Legislativo (Congresso Nacional) e do Poder Judiciário (Supremo Tribunal Federal) ante esse uso do Poder Executivo.

Uma análise da medida provisória à luz do princípio democrático requer a consideração de algumas premissas.

Inicialmente - e dizer isto é já um truísmo - a análise não pode ignorar que medida provisória e princípio democrático possuem status constitucional, o que, por si só e de imediato, afasta argumentos e conclusões simplistas sobre a relação entre essas duas variáveis. Depois, tenha-se presente que o princípio democrático é uma norma-princípio que incide sobre a produção normativa. A medida provisória é veículo de normas, um instrumento de inovação normativa do sistema jurídico, logo o seu uso deve estar em harmonia (concordância prática) com o princípio democrático. Como terceira premissa, postula-se que uma correta compreensão jurídico-constitucional da relação entre medida provisória e princípio democrático no plano da concretização constitucional requer uma interpretação sistemática da Constituição.

\subsection{Compatibilidade no plano da normatividade constitucional abstrata}

Inicialmente, há que se perguntar se, no plano da normatividade constitucional abstraía, a medida provisória é compatível com o princípio democrático. A resposta é positiva. Em primeiro lugar, pela simples razão de que no Brasil não se adotou a tese da inconstitucionalidade das normas constitucionais originárias. Se interpretadas e aplicadas em conformidade com a disciplina constitucional (até mesmo no regime anterior à EC 32/2001), a medida provisória é plenamente compatível com o princípio democrático. Na CF (antes e também depois da EC 32/2001), a medida provisória é instrumento legislativo excepcional e emergencial de competência do Presidente da República. O Chefe do Poder Executivo federal está autorizado a editá-la apenas em casos de urgência e relevância; a medida provisória editada tem caráter provisório e sua conversão em lei depende da aprovação do Congresso Nacional. A não-apreciação pelo Congresso Nacional implicava, antes da EC 32/2001, rejeição tácita. Tal como disciplinada na CF, tanto antes como depois da EC 32/2001, a medida provisória não representa transferência de ilimitados poderes legislativos ao Poder Executivo; não subtrai do Congresso Nacional a função precípua de legislar; não inverte a posição preferente da lei parlamentar como mecanismo de inovação do ordenamento jurídico, e, por conseguinte, não esbulha a soberania popular, não esvazia a representação democrática e não constrange o pluralismo político.

Segundo Ávila,

“(...) a produção de normas, especialmente pelo Poder Executivo, deve obedecer ao princípio democrático. A edição de medidas provisórias não 
envolve nem participação, nem representatividade popular anteriores à eficácia do ato, e diretamente relacionada ao seu conteúdo. A participação do Congresso Nacional, por meio da lei de conversão, estabelecida pela $\mathrm{CF}$ para atribuir estabilidade aos efeitos transitórios da medida provisória, assume especial relevância para a preservação do princípio democrático" ${ }^{20}$

Retomando assertiva anterior, no ato de editar medida provisória também se dá a otimização do princípio democrático, embora em menor grau do que na produção legislativa congressual típica. A medida provisória representa uma certa restrição ao princípio democrático - mas não a supressão - em prol de outras finalidades constitucionalmente legítimas, tais como permitir que a fração executiva do poder estatal apresente solução normativa para situações de relevância e urgência, não viabilizáveis em tempo razoável por meio do processo legislativo típico.

Com vistas à refutação da tese adotada, poder-se-ia invocar o argumento do poder (do efeito) fático-político da medida provisória. Segundo esse argumento, a medida provisória é um instrumento que confere demasiado poder ao Poder Executivo, "[...] porque a edição de uma medida provisória implica a imediata alteração do status quo. Ao analisá-la, o Congresso não opta entre o status quo anterior (SQ) e aquele a ser produzido pela promulgação da medida (SQmp), mas sim entre o SQmp e uma situação em que a MP é rejeitada após ter vigorado e surtido efeito (MPrej)". ${ }^{21}$ Com a medida provisória, o Poder Executivo altera unilateralmente o status quo. Em muitos casos, "dado o custo de rejeição de uma MP, os parlamentares podem julgar preferível aprová-la, tendo em vista os efeitos já produzidos durante sua vigência". ${ }^{22}$ Trata-se da política do fato consumado, o que inibe a discussão da medida provisória editada e a proposição de alternativas por aqueles parlamentares que dão sustentação ao Poder Executivo (ao governo) e, sobremaneira, por aqueles que a ele se opõem. Tomem-se como exemplos paradigmáticos as medidas provisórias que criaram o Plano Verão (governo José Sarney, fevereiro de 1989), o Plano Collor I (governo Fernando Collor, março de 1990) e o Plano Real (governo Itamar Franco, 1994). Os parlamentares foram postos diante do seguinte dilema: ou a aprovação das medidas provisórias editadas, ou o caos econômico e social. Cite-se como paradigmática a Medida Provisória n 168, de 15 de março de 1990 (Plano Collor I), que instituiu o cruzeiro em substituição ao cruzado novo, dispôs sobre a liquidez do mercado financeiro e deu outras providências complementares para a reforma monetária.

20 Humberto Ávila, Medida Provisória na Constituição de 1988, p. 52.

21 Argelina Cheibub Figueiredo e Fernando Limongi, Executivo e Legislativo na nova Ordem Constitucional. p. 26. Em nome da honestidade intelectual, esclareça-se, de imediato, que os autores discutem este argumento em outro contexto, a saber, por ocasião da análise das bases institucionais do presidencialismo de coalizão. Ao menos no referido texto, não apresentam o argumento como contraponto ao princípio democrático. Portanto, a utilização do argumento como tentativa de falseamento da tese da compatibilidade da medida provisória com o princípio democrático é de inteira responsabilidade do autor do presente trabalho.

22 Id., ibid., p. 38. 
Não há dúvida de que o argumento descreve o que freqüentemente ocorre nas relações entre Poder Executivo e Poder Legislativo, sobretudo por ocasião da edição de medidas provisórias institucionalizadoras de programas econômicos de amplo, profundo e imediato impacto. De fato, nesses casos a pressão política - exercida pelo Poder Executivo e muitas vezes pela mídia e por setores sociais organizados e influentes - sobre o Congresso Nacional é muito forte.

Contudo, aqui interessa saber se esse argumento remia a tese da compatibilidade constitucional, in abstracto, da medida provisória com o princípio democrático. De um ponto de vista estritamente jurídico-constitucional, não. Primeiramente, porque a CF inclui a medida provisória no âmbito do processo legislativo (art. 59, V) e determina a submissão imediata (das medidas provisória editadas), para conversão em lei, ao Congresso Nacional (isso antes e depois da EC 32/2001). Não havia e não há qualquer obstáculo constitucional à rejeição parlamentar de medidas provisórias. Segundamente, porque a CF consagra o princípio da separação de poderes (art. $2^{\circ}$ ), o que implica a autonomia e independência do Poder Legislativo ante o Poder Executivo. Do ponto de vista estritamente jurídico-constitucional, é frágil o argumento de que medida provisória editada, ao produzir fatos econômicos e sociais relevantes antes da apreciação do Congresso Nacional, fere o princípio democrático. O Congresso Nacional não está juridicamente (e politicamente) obrigado a aprovar medidas provisórias editadas pelo Poder Executivo, seja em que situação for. Compete ao Poder Legislativo verificar a presença dos pressupostos de admissibilidade (formais e materiais), analisar o mérito e decidir soberanamente. Ante a autonomia e independência do Poder Legislativo, constitucionalmente garantidas, não há que se falar em política de fatos consumados.

3.2 Os Poderes Públicos, o uso da medida provisória antes da EC 32/2001 e o princípio democrático

\subsubsection{Poder Executivo}

Os Presidentes da República após-88 editaram e reeditaram medidas provisórias de modo avassalador. Desde o início da vigência da $\mathrm{CF}$, em 5.10.1988, até a promulgação da EC 32, em 11.9.2001 (publicação no Diário Oficial da União em 12.09.2001), foram (i) editadas 619 medidas provisórias (originárias), (ii) reeditadas 5.491 medidas provisórias, (iii) totalizando, somadas edições e reedições, 6.110 medidas provisórias. ${ }^{23}$

23 Esses e outros dados sobre edição e reedição de medidas provisórias por governo e ano de publicação, no período anterior à EC 32 de 11.09.2001, encontram-se disponíveis no site da Presidência da República Federativa do Brasil. (O endereço de acesso em 20 de abril de 2004 era www.planalto.gov.br/ccivil_03/MPV/Quadro/Ogovemo.doc.) As fontes desses dados são a Casa Civil da Presidência da República (Subchefia para Assuntos Jurídicos) e a Secretaria Geral da Presidência da República (Secretaria de Assuntos Parlamentares). 
Na prática, com o uso frenético da medida provisória, o Poder Executivo tornou-se o principal legislador da República Federativa do Brasil; ampliou extraordinariamente seus poderes legislativos; extrapolou significativamente suas competências para inovar a ordem jurídica. A competência juridicamente delimitada, a que se refere Ávila (ver supra), converteu-se em competência juridicamente ilimitada. Para o Poder Executivo, praticamente, todas as matérias passíveis de providência legislativa tornaram-se relevantes e urgentes. E em virtude do número de reedições, de caráter provisório conforme prescreve o texto constitucional a medida provisória passou a ter caráter definitivo conforme a práxis. ${ }^{24} \mathrm{E}$ mais: ao reeditar medidas provisórias, com frequiência faziam-se modificações, supressões e acréscimos, gerando dúvida sobre quais seriam as normas vigentes, violando-se os princípios da certeza jurídica e da proteção da confiança. ${ }^{25}$

Definitivamente, eram inconstitucionais a interpretação e aplicação que fazia o Poder Executivo do instrumento da medida provisória antes da EC 32/2001; violavam o princípio democrático, bem como o da separação de poderes.

24 O recurso à reedição, em certos casos, alcançou números surrealistas: houve medidas provisórias reeditadas ao longo de seis ou mais anos. Citem-se alguns exemplos: (i) MP 2.176-79, de 23.8.2001 (MP originária: 1.110), convertida na Lei 10.522, de 19.7.2002 - Dispõe sobre o Cadastro Informativo dos créditos não quitados de órgãos e entidades federais e dá outras providências; (ii) MP 2.084-72, de 22.2.2001 (MP originária: 1.109. de 29.8.1995), convertida na Lei 10.206. de 23.3.2001 - Altera a legislação referente ao Adicional ao Frete para a Renovação da Marinha Mercante - AFRMM e ao Fundo da Marinha Mercante - FMM, e dá outras providências: (iii) MP 2.114-75, de 26.1.2001 (MP originária: 964. de 30.3.1995), convertida na Lei 10.199, de 14.2.2001 - Dá nova redação aos arts. $6^{\circ}$ e $9^{\circ}$ da Lei $n^{\circ} 8.019$, de 11 de abril de 1990 , e acresce dispositivo à Lei $\mathrm{n}^{\circ}$ 9.365, de 16 de dezembro de 1996: (iv) MP 2.074-73, de 25.1.2001 (MP originária: 1.053, de 30.6.1995), convertida na Lei 10.192, de 14.2.2001 - Dispõe sobre medidas complementares ao Plano Real e dá outras providências; (v) MP 2.112-88, de 27.12.2000 (MP originária: 480, de 27.4.94), convertida na Lei 10.180, de 6.2.2001 - Organiza e disciplina os Sistemas de Planejamento e de Orçamento Federal, de Administração Financeira Federal, de Contabilidade Federal e de Controle Interno do Poder Executivo Federal, e dá outras providências: (vi) MP 2.096-89, de 25.1.2001 (MP originária: 470, de 11.4.1994), convertida na Lei 10.179, de 6.2.2001 - Dispõe sobre os títulos da dívida pública de responsabilidade do Tesouro Nacional, consolidando a legislação em vigor sobre a matéria; (vii) MP 1.982-77, de 23.11.2000 (MP originária: 794, de 29.12.1994), convertida na Lei 10.101, de 19.12.2000 - Dispōe sobre a participação dos trabalhadores nos lucros ou resultados da empresa e dá outras providências.

25 A segurança jurídica e a proteção da confiança são subprincípios concretizadores do princípio do Estado de Direito (J. J. Gomes Canotilho, Direito Constitucional e Teoria da Constituiçāo, p. 250). Enquanto a segurança jurídica está conectada à garantia da estabilidade jurídica, segurança de orientação e realização do direito (elementos objetivos da ordem jurídica), a proteção da confiança prende-se à calculabilidade e previsibilidade dos indivíduos ante os atos normativos dos poderes públicos (elementos subjetivos da ordem jurídica). "A segurança e a proteção da confiança exigem, no fundo: (1) fiabilidade, clareza, racionalidade e transparência dos actos do poder: (2) de forma que em relação a eles o cidadão veja garantida a segurança nas suas decisões pessoais e nos efeitos jurídicos dos seus próprios actos" (id., ibid.). 


\subsubsection{Poder Legislativo (Congresso Nacional)}

Como já mencionado, até o século XX, competências legislativas eram, em regra, exclusivas do Poder Legislativo. Em virtude da crescente complexidade das sociedades e da ampliação da intervenção estatal em domínios antes reservados ao setor privado - e também da criação de novos domínios pelo próprio Estado dotou-se o Poder Executivo de poderes legislativos excepcionais.

No campo da Ciência Política, há três teses para explicar a perda parcial de poderes legislativos do Poder Legislativo e o correspondente ganho do Poder Executivo: tese da abdicação, tese da usurpação e tese da delegação. ${ }^{26}$ Segundo a tese da abdicação, o Poder Legislativo pura e simplesmente abdicou da função legislativa em favor do Poder Executivo. Contra essa tese, no contexto brasileiro, argumenta-se que ela implica um paradoxo, pois afinal de contas foi o Poder Constituinte (representado por uma Assembléia democraticamente eleita) que escreveu a Constituição. Seria plausível supor que o Poder Legislativo, ao abdicar de prerrogativas por definição suas, tenha desenhado um quadro institucional desfavorável a si mesmo? Segundo a tese da usurpação, o Poder Executivo usurpou o poder de legislar do Poder Legislativo. Essa tese se defronta, em parte, com a mesma objeção à tese da abdicação: o Poder Constituinte escreveu a Constituição. É correto dizer que há situações nas quais efetivamente há uma usurpação. Na tradição constitucional brasileira, é verdadeiro dizer que houve usurpação com a Emenda Constitucional ${ }^{\circ}$ 1/1969, que adotava o decreto-lei. A usurpação foi operada por um Poder Executivo autoritário, ditatorial. "Separação de poderes" e "democracia", naquele contexto, eram expressões estranhas ao léxico do poder institucionalizado. Segundo a tese da delegação, o Poder Legislativo delegou "[...] poderes legislativos ao Executivo visando superar problemas de ação coletiva, coordenação e instabilidade das decisões aos quais estaria particularmente sujeito. A delegação visaria, assim, a garantir mais estabilidade às decisões e maior eficiência aos resultados de políticas. Ou seja, a delegação de poderes ao Executivo não impediria o Legislativo de alcançar os objetivos por ele desejados". ${ }^{27}$ Segundo essa tese, a delegação pode ser vantajosa também para o Poder Legislativo, porque "[...] poderes legislativos excepcionais nas mãos do Executivo podem propiciar ganhos para o Legislativo e resultar em cooperação entre os dois poderes" ${ }^{28}$

São teses explicativas formuladas no marco da Ciência Política. É preciso verificar se elas encontram abrigo no plano da dogmática constitucional.

Tratando-se de medida provisória (tanto antes como depois da EC 32/2001), de imediato são afastáveis as teses da abdicação e da usurpação, afinal de contas a CF foi produzida por uma Assembléia Constituinte democrática - é bem verdade que

26 Cf. Argelina Cheibub Figueiredo e Fernando Limongi, Executivo e Legislativo na nova Ordem Constitucional, p. 125 et seq.

27 Id., ibid., p. 126.

28 Id., ibid., p. 126. 
não-exclusiva. ${ }^{29}$ Do ponto de vista estritamente jurídico-constitucional, a medida provisória é delegação de competência legislativa excepcional ao Poder Executivo. Poderia se argumentar que o uso abusivo da medida provisória pelo Poder Executivo constitui usurpação fática. Contudo, esse argumento é facilmente refutável. Considerando-se que o Congresso Nacional brasileiro dispõe da via jurídico-constitucional (podendo emendar a Constituição, mudando já no texto constitucional o instituto da medida provisória - o que finalmente fez por meio da EC 32/2001) e da via político-constitucional (análise dos pressupostos materiais de admissibilidade; o Congresso Nacional está autorizado a decidir sobre a urgência e relevância das medidas provisórias editadas), é razoável dizer que havia, no período anterior à EC 32/2001, na pior das hipóteses, uma abdicação fática voluntária, do Congresso Nacional, dos poderes legislativos em favor do Poder Executivo. Contudo, essa abdicação fática representava uma renúncia de competência legislativa não amparada no texto constitucional. $\mathrm{O}$ legislador ordinário não estava autorizado nem obrigado pela CF a ser cúmplice do ativismo legislativo do Poder Executivo. Antes pelo contrário, os dispositivos constitucionais que disciplinavam a medida provisória (antes da EC 32/2001) e os princípios e regras constitucionais relativos à produção normativa fundamentavam o dever de o Poder Legislativo fazer com que o Poder Executivo se contivesse e operasse sua competência legislativa nos limites constitucionalmente delimitados. Ao omitir-se, o Poder Legislativo não se vinculava à $\mathrm{CF}$, porque não fazia valer sua competência nela definida. O legislador ordinário não estava autorizado a renunciar, no plano fático, às competências que a CF lhe atribuía.

No que se refere à questão principal aqui analisada, enfatize-se que, ao permitir o uso abusivo da medida provisória no período anterior à EC 32/2001, o Poder Legislativo não atentou para o princípio democrático, porque não exerceu em sua plenitude a representação democrática, elemento constitutivo do princípio democrático, e enfraqueceu a lei parlamentar como forma privilegiada da ordenação normativa vinculante da vida social. De certa forma, portanto, não se vinculou à soberania popular, porque não exerceu a porção de titularidade do domínio político que a vontade popular lhe delegou. Em outros termos, o Poder Legislativo, ao não exercer em sua plenitude os poderes que lhe conferiu o Poder Constituinte Originário, não se reconduziu ao povo, de quem emana todo o poder.

\subsubsection{Supremo Tribunal Federal}

Por fim, analise-se a posição do Supremo Tribunal Federal sobre o uso da medida provisória antes da EC 32/2001. Aqui, duas questões são relevantes: (i) a dos pressupostos materiais para edição de medida provisória e (ii) a da reedição de medidas provisórias.

(i) A jurisprudência constante do STF entendia que o exame (avaliação) dos pressupostos da relevância e da urgência era, em princípio, de competência da

29 Assembléia Constituinte e Congresso Nacional eram um mesmo corpo com funções distintas. Os eleitos em 15 de novembro de 1986 acumularam, individualmente, as funções constituinte e legislativa ordinária. 
Presidência da República e do Congresso Nacional, porque é uma avaliação de caráter político, subjetiva, condicionada a um juízo de oportunidade e de valor. Contudo, entendia, também, que os pressupostos admitiam o controle judicial do "excesso do poder de legislar". Verificada objetivamente a ausência de urgência e/ou relevância. o STF deveria decidir pela ilegitimidade constitucional da medida provisória editada por "excesso do poder de legislar" ${ }^{30} \mathrm{Na}$ ADInMC n $1.753-\mathrm{DF},{ }^{31}$ com a qual se atacava a inconstitucionalidade do art. $4^{\circ}$. caput e parágrafo único da Medida Provisória $n^{\circ} 1.577-6 / 97,{ }^{32}$ o STF considerou não atendido o pressuposto da urgência e, invocando a teoria do "excesso do poder de legislar", deferiu o pedido de liminar.

Essa interpretação flexível dos pressupostos da medida provisória encontrava resistência no próprio STF. Crítico persistente era o Ministro Marco Aurélio de Mello, cujo núcleo da argumentação encontrava-se, por exemplo, exposto em voto proferido na $\mathrm{ADInMC} \mathrm{n}^{\circ} 1.516-\mathrm{RO}$ :

“(...) não podemos afastar do crivo do Supremo Tribunal Federal os requisitos previstos no artigo 62 da Constituição da República, para que se tenha a atuação. como legítima, sob o ângulo constitucional. do Presidente da República. Refiro-me à urgência e à relevância da questão. Os requisitos são constitucionais. e se está na própria Constituição Federal que o Supremo Tribunal Federal dela é o guarda, não tenho como dizer que não cabe à Corte o exame do tema". 33

Também na doutrina o entendimento do STF era alvo de crítica. $\mathrm{O}$ argumento principal dizia que urgência e relevância não estão no plano da discricionariedade; são, na verdade, conceitos jurídicos indeterminados, dotados de ambiguidade e vagueza, densificáveis com base em uma interpretação sistemática dos princípios e regras constitucionais conexos aos dispositivos disciplinadores da medida provisória. ${ }^{34}$

30 ADInMC 162-DF, Rel. Moreira Alves, 14.12.89; ADInMC 1.397-DF, Rel. Carlos Velloso, 28.4.1997, cf. Revista de Direito Administrativo (RDA) 210/294-299; ADIn 1.647-PA, Rel. Carlos Velloso. 2.12.1998, cf. RTJ 168/774-787; RE n ${ }^{\circ} 222.719-\mathrm{PB}$, Segunda Turma, Rel. Carlos Velloso. 14.12.1998. cf. RTJ 168/674-681.

31 Relator Ministro Sepúlveda Pertence, cf. RTJ 172/32-41.

32 "Art. $4^{\circ}$. O direito de propor ação rescisória por parte da União, dos Estados, do Distrito Federal, dos Municípios, bem como das autarquias e das fundações instituídas pelo Poder Público extingue-se em cinco anos, contados do trânsito em julgado da decisão.

Parágrafo único: Além das hipóteses referidas no artigo 485 do Código de Processo Civil, será cabivel ação rescisória quando da indenização fixada em ação de desapropriação, em ação ordinária de indenização por apossamento administrativo ou desapropriação indireta, e também em ação que vise a indenização por restrições decorrentes de atos do Poder Público, em especial aqueles destinados à proteção ambiental, for flagrantemente superior ao preço de mercado do bem objeto da ação judicial."

33 Relator Ministro Sydney Sanches, cf. RTJ 170/831.

34 Cf. BANDEIRA DE MELLO, Celso Antônio. "Perfil constitucional das medidas provisórias". Revista de Direito Público, São Paulo. v. 23, n 95, p. 28-32, jul./set. de 1990: DERZI. Misábel de 
(ii) Para o STF, a reedição de medida provisória não rejeitada expressamente pelo Congresso Nacional não era ato inconstitucional da Presidência da República. ${ }^{35}$ Argumentação representativa do entendimento prevalecente no STF estava no voto do Ministro Carlos Velloso na ADInMC n 1.397-DF: "a reedição da medida provisória não rejeitada pelo Congresso Nacional, ao contrário do alegado, não é dado configurador da inocorrência dos requisitos de urgência e relevância. Ao contrário, a reedição demonstra, de certa forma, a necessidade da medida e a sua urgência". ${ }^{36}$ Para a maioria dos ministros do STF, a reedição de medida provisória não rejeitada pelo Congresso Nacional não violava o princípio da separação de poderes, porque o silêncio do Congresso Nacional ante uma medida provisória editada pelo Poder Executivo não é uma não-decisão; é, sim, uma decisão política legítima. Isso é o que se lê no voto do Ministro Sepúlveda Pertence na ADInMC 1.516-RO:

“(...) de um lado, reafirmando o que acentuei em diversas decisões individuais denegatórias de liminar e que o Plenário referendou, dentre outras, na ADIn 1.314, relatada pelo Ministro Ilmar Galvão, é evidente que as reedições sucessivas, ao fim do prazo, das medidas provisórias não ofendem o princípio da independência do Poder Legislativo na medida em que o seu contraforte está numa das primeiras decisões tomadas pelo Tribunal, na construção da jurisprudência brasileira da medida provisória, quando se reputou, de modo absoluto, a reedição, se rejeitada explicitamente pelo Congresso Nacional (ADIn 293, Celso, 6-6-90, RTJ 146/707; LEX 178/54). O juízo de rejeitar expressamente a medida provisória ou deixar que, com o silêncio a respeito, fique aberta a porta à reedição, este sim, é um típico juízo político do Congresso Nacional". ${ }^{37}$

A legitimidade constitucional da reedição de medida provisória também era motivo de dissenso no próprio STF. Mais uma vez, o Ministro Marco Aurélio era o dissidente principal:

“(...) coaduna-se com o texto do artigo 62 essa reedição sucessiva da medida provisória? A resposta é desenganadamente negativa. Primeiro, porque se previu o prazo de trinta dias e, além dessa previsão, se disse que o Congresso, esgotada a dilação, deveria disciplinar as relações jurídicas surgidas no período de vigência da medida provisória.

Abreu Machado. “Medidas provisórias - sua absoluta inadequação à instituição e majoração de tributos”. Revista de Direito Tributário, São Paulo, $n^{\circ} 45$, p. 130-42, jul./set. de 1988; e Humberto Ávila, Medida provisória na Constituição de 1988, p. 78-88.

35 ADIn 295-DF; ADInMC 1.397-DF; ADInMC 1.516-RO; ADIn 1.610-DF; ADIn 1.135-DF; ADIn 1.647-PA.

36 Relator Ministro Carlos Velloso, cf. RDA 210/297-8.

37 Relator Ministro Sidney Sanches, cf. RTJ 170/834-835. 
Em segundo lugar, se voltarmos à cabeça do artigo 62, a cláusula final nele contida, veremos que realmente considerou-se esse prazo de trinta dias como um prazo definitivo, como algo substancial, como algo que, portanto, deveria ser observado. O que está previsto nessa parte final? Estando o Congresso nacional em recesso, será ele convocado extraordinariamente para reunir-se no prazo de cinco dias.

\section{$[\ldots]$}

Senhor Presidente, por mais que me esforce, não consigo chegar a outra conclusão. A reedição das medidas provisórias, as reedições sucessivas fazem-se à margem, a mais não poder, do teor da Carta da República, com consequiências - pelo menos sob a minha óptica, e com a devida vênia daqueles que entendem de forma diversa - nefastas, em face do círculo vicioso que conduz a uma acomodação do próprio Congresso Nacional, passando o Chefe do Poder Executivo a ser o legislador da Nação". ${ }^{38}$

Interessa, aqui, perguntar se a jurisprudência do STF sobre o uso de medidas provisórias encontrava amparo no princípio democrático, que é, reitere-se, relevante princípio relativo à produção normativa.

Que sobre as funções do Congresso Nacional e do Poder Executivo incide o princípio democrático é tese que não se discute. Motivo de análise e reflexão, ainda, é a incidência desse princípio sobre as atividades jurisdicionais; afinal, juízes, desembargadores e ministros não são eleitos pelo povo.

Sustenta-se aqui que o Poder Judiciário também está vinculado ao princípio democrático. Em que sentido? No sentido de que o Poder Judiciário se legitima democraticamente ao vincular-se, formal e materialmente, à Constituição - instituída pelo Poder Constituinte Originário e emendada pelo Poder Constituinte Derivado, poderes que se reconduzem ao "poder constituinte do povo" 39 , cujo momento inaugural é a soberania popular - e à lei, principal produto da realização do princípio da representação democrática. ${ }^{40}$ Enfatize-se que a legitimidade democrática do Poder Judiciário não se exaure nem se cristaliza de uma vez por todas porque foi instituído pela vontade do poder constituinte do povo. Em outros termos, a legitimação não se finaliza no momento inaugural do Poder Constituinte (Originário). O Poder Judiciá-

38 ADIn n 1.647-PA (Tribunal Pleno, Relator Ministro Carlos Velloso), cf. RTJ 168/785-6.

39 Ernst Wolfgang Böckenförde, "La democracia como principio constitucional", p. 50-1.

40 Trata-se, na terminologia de Böckenförde ("La democracia como principio constitucional", p. 65), de uma legitimação democrática material ou de conteúdo. Segundo o constitucionalista alemão, "a forma material ou de conteúdo da legitimação democrática tem por objeto assegurar que, no que se refere a seu conteúdo, o exercício do poder do Estado deriva do povo ou se concilia com a vontade do povo, e que desta forma se garante o exercício do poder do Estado pelo povo" (id., ibid., p. 62). 
rio deverá vincular-se permanentemente à vontade do povo, é dizer, à Constituição e à lei. ${ }^{41}$ Trata-se de uma legitimação democrática continuada.

Essa compreensão da vinculação do Poder Judiciário ao princípio democrático tem graves implicações para a questão do uso da medida provisória. A primeira: o Poder Judiciário, em especial o STF, porque é a corte suprema do país, deve vincular-se de forma rigorosa ao texto constitucional, ponto de partida e limite das possibilidades interpretativas. ${ }^{42} \mathrm{~A}$ segunda: a inaceitabilidade da premissa não explícita segundo a qual se o Congresso Nacional por omissão mantém-se aquém das suas competências legislativas definidas na CF permitindo que o Poder Executivo vá além das competências legislativas constitucionalmente definidas, então não cabe ao STF reequilibrar ou restaurar as competências legislativas, de um poder e de outro, em conformidade com a CF. O argumento, nas decisões do STF, de que a configuração da relevância e urgência e a possibilidade de reedição de medidas provisórias dependem de um juízo político da Presidência da República e do Con-

41 Sobre a legitimação democrática do Poder Judiciário operada pela vinculação ao Direito, escreveu Müller: “onde funcionários públicos e juízes não chegam ao seu cargo por meio de uma eleição pelo povo, a sua ação se liga de forma demasiado etérea à ação originária do povo ativo à eleição de parlamentares que colaboraram na promulgação de textos de normas, que foram depois implementadas de forma defensável no Executivo e no Judiciário. Por essa razão deveríamos formular a pergunta aqui já de forma diferente. É certo que no caso ideal as coisas se apresentam da seguinte maneira: textos de normas democraticamente instituídos são ius civile. Quando eles são respeitados no trabalho cotidiano dos juristas (tratamento do caso, decisão com caráter de obrigatoriedade, controle e revisão) como vinculantes e observados de forma correspondentemente séria no tocante ao método, o trabalho jurídico permanece no discurso do direito popular. Ele não resvala para um ius honorarium; no Estado Democrático de Direito, o jurista não pode brincar de pretor romano. Os poderes 'executantes' ['ausführenden'] Executivo e Judiciário não estão instituídos e não são apenas controlados conforme o Estado de Direito; estão também comprometidos com a democracia. O povo elege os seus representantes; do trabalho dos mesmos resultam (entre outras coisas) os textos das normas; estes são, por sua vez, implementados nas diferentes funçōes do aparelho de Estado; os destinatários, os atingidos por tais atos são potencialmente todos, a saber, o 'povo' enquanto população. Tudo isso forma uma espécie de ciclo [Kreislauf] de atos de legitimação, que em nenhum lugar pode ser interrompido (de modo não-democrático)" (MÜLLER, Friedrich. Quem é o povo? A questão fundamental da democracia. Trad. de Peter Naumann. São Paulo: Max Limonad, 1998, 59-60). Segundo Müller, o ius civile (direito popular da Roma antiga elaborado com a participação dos cidadãos), em sentido atual, são "[...] prescriçōes de direito geradas por meio de procedimentos constitucionais democráticos" (ibid., p. 59, nota de rodapé 41). Sobre o ius honorarium, explica Müller: "no sentido do Direito Romano: o direito criado durante a época da República pelos magistrados judiciais do patriciado (ius praetorium), que foi elaborado sem a participação do povo, i. é, de forma não-democrática. - A alusão a esse exemplo histórico no texto acima significa que a constituição moderna de uma democracia em um Estado de Direito não permite mais nenhum direito (e.g. judicial) que se desliga das diretivas das leis democraticamente promulgadas (e.g. como 'direito jurisprudencial' livremente criado); ela significa, portanto, que o juiz no Estado democrático de Direito não se pode comportar como um pretor romano" (ibid., p. 60 , nota de rodapé 42 ).

42 Sobre a tese do texto constitucional como ponto de partida e limite das possibilidades interpretativas, ver: MỨLLER, Friedrich. Métodos de trabalho do Direito Constitucional. Trad. de Peter Naumann. 2. ed. rev. São Paulo: Max Limonad, 2000, p. 53 et seq. e 71 et seq. 
gresso Nacional resulta, ao que parece, da referida premissa não explícita, não assumida expressamente. Diante da extrapolação competencial do Poder Executivo e da renúncia fática, pelo Congresso Nacional, das competências constitucionais típicas, cabe ao STF fazer um ajuste das competências em conformidade com a CF, sob pena, entre outras conseqüências, do esbulho da soberania popular, do esvaziamento da representação democrática e da restrição ao pluralismo político; enfim, da violação do princípio democrático.

Referências bibliográficas

ALEXY, Robert. Teoria de los derechos fundamentales. $1^{a}$ reeimpressão. Madri: Centro de Estúdios Constitucionales, 1997.

ASENSI SABATER, José. La época constitucional. Valência: Tirant lo Blanch, 1998.

ÁVILA. Humberto Bergmann. Medida provisória na Constituição de 1988. Porto Alegre: S. A. Fabris, 1997.

BANDEIRA DE MELLO, Celso Antônio. "Perfil constitucional das medidas provisórias”. Revista de Direito Público, São Paulo, v. 23, nº 95, p. 28-32, jul/set. 1990.

BOBBIO, Norberto. O futuro da democracia: uma defesa das regras do jogo. Trad. de Marco Aurélio Nogueira. 5. ed. Rio de Janeiro: Paz e Terra, 1992.

. Estado, governo, sociedade: para uma teoria geral da política. Trad. de Marco Aurélio Nogueira. 6. ed. Rio de Janeiro: Paz e Terra, 1997.

BÖCKENFÖRDE, Ernst Wolfgang. "La democracia como principio constitucional". In: BÖCKENFÖRDE, Ernst Wolfgang. Estúdios sobre el Estado de Derecho y la democracia. Madri: Trotta, 2000. p. 47-131.

CANOTILHO, J. J. Gomes. Direito Constitucional e Teoria da Constituição. 2. ed. Coimbra: Almedina, 1999.

CLĖVE, Clèmerson Merlin. Medidas provisórias. 2. ed. rev. ampl. São Paulo: Max Limonad, 1999.

DERZI, Misabel de Abreu Machado. "Medidas provisórias - sua absoluta inadequação à instituição e majoração de tributos". Revista de Direito Tributário, São Paulo, nº 45, p. 130-42, jul/set. de 1988.

FIGUEIREDO, Argelina Cheibub; LIMONGI, Fernando. Executivo e Legislativo na nova ordem constitucional. São Paulo: Ed. FGV, Fapesp, 1999.

HESSE, Konrad. Elementos de Direito Constitucional da República Federal da Alemanha. Trad. de Luís Afonso Heck. Porto Alegre: S. A. Fabris, 1998.

MÜLLER. Friedrich. Quem é o povo? A questão fundamental da democracia. Trad. de Peter Naumann. São Paulo: Max Limonad, 1998.

. Métodos de trabalho do Direito Constitucional. Trad. de Peter Naumann. 2. ed. rev. São Paulo: Max Limonad, 2000.

PÉREZ LUÑO, Antônio Henrique. Derechos humanos. Estado de Derecho y Constitución. 6. ed. Madri: Tecnos, 1999.

SILVA, José Afonso da. Curso de Direito Constitucional Positivo. 9. ed. rev. [4 ${ }^{\text {a }}$ tiragem]. São Paulo: Malheiros, 1994. 